\title{
CARDAMINE OCCULTA HORNEM. - A NEW CONCEALED ALIEN PLANT IN THE FLORA OF CROATIA
}

\section{Dario Hruševar ${ }^{1}$, Josip Mesaroš ${ }^{2}$, Dalibor Vladović $^{3}$, Anita Vucić ${ }^{4}$, Igor Belamarićc ${ }^{5}$, Lidjua Suraćc ${ }^{6} \&$ Božena Mitić ${ }^{1 *}$}

${ }^{1}$ University of Zagreb, Faculty of Science, Department of Biology, Rooseveltov trg 6a, HR-10000,

Zagreb, Croatia ("corresponding author: bozena.mitic@biol.pmf.hr)

${ }^{2}$ Colić-trade d.o.o. - Agrocentar; Kakma b.b., HR-23423, Polača, Croatia

${ }^{3}$ Natural History Museum, Poljana kneza Trpimira 3, HR-21000, Split, Croatia

${ }^{4}$ Institute of Public Health Zadar, Kolovare 2, HR-23000, Zadar, Croatia

${ }^{5}$ Parkovi i nasadi d.o.o., Kavanjinova 12, HR-21000 Split, Croatia

${ }^{6}$ Rasadnik Piket d.o.o.; Ulica 1, br. 30., HR-23222 Zemunik Donji, Croatia

Hruševar D., Mesaroš J., Vladović D., Vucić A., Belamarić I., Surać L. \& Mitić, B.: Cardamine occulta Hornem. - a new concealed alien plant in the flora of Croatia. Nat. Croat., Vol. 30, No. 1., 207-215, Zagreb, 2021.

In the last decade of the 20th and in the early 21st century a new plant from East Asia, Cardamine occulta, was recorded in many European countries, and evaluated as a potential invasive species. Prior to our research, it had not been observed in Croatia or the neighbouring countries. During 2017, the first plants of $C$. occulta were discovered in plant nurseries in Zemunik Donji (near the city of Zadar), and in the city of Split. Since then, both sites have been monitored continuously, and the populations in both nurseries are still present and getting denser every year. In this work we aim to present a short history of the discovery, list newly-detected sites and establish some features (taxonomical peculiarities, plant description, distribution, growth and invasive preferences) of the species C. occulta to make its identification easier. Because of its invasive potential and morphological similarity with two other taxa distributed in Croatia, C. hirsuta and C. flexuosa, the determination key for all three taxa, as well as photos of C. occulta have been prepared. This will probably increase the chance of early detection of this species outside of cultivation.

Key words: Cardamine L., Europe, family Brassicaceae, invasive plants, non-native flora, weed

Hruševar D., Mesaroš J., Vladović D., Vucić A., Belamarić I., Surać L. \& Mitić, B.: Cardamine occulta Hornem. - nova pritajena alohtona biljka u flori Hrvatske. Nat. Croat., Vol. 30, No. 1., 207-215, Zagreb, 2021.

U posljednjem desetljeću 20. i početkom 21. stoljeća u mnogim je europskim zemljama zabilježena nova biljka iz istočne Azije, Cardamine occulta, koja je procijenjena potencijalno invazivnom vrstom. Prije našeg istraživanja nije opažena u Hrvatskoj ili susjednim zemljama. Tijekom 2017. godine otkrivene su prve biljke C. occulta u rasadnicima biljaka u Zemuniku Donjem (u blizini grada Zadra) i u gradu Splitu. Od tada se oba nalazišta kontinuirano prate, a populacije na oba nalazišta i dalje su prisutne i svake su godine sve gušće. Ciljevi ovog rada bili su predstaviti kratku povijest istraživanja i obilježja novootkrivenih nalazišta te utvrditi neke značajke (taksonomske osobitosti, opis biljaka, rasprostranjenost, uzgojne i invazivne preferencije) vrste C. occulta, kako bismo olakšali njezinu identifikaciju. Zbog svog potencijalnog invazivnog karaktera i morfološke sličnosti s dvije vrste prisutne $u$ Hrvatskoj, C. hirsuta i C. flexuosa, pripremljen je i ključ za determinaciju sve tri slične svojte te fotografije C. occulta. To će vjerojatno povećati mogućnost za rano otkrivanje ove vrste izvan uzgoja.

Ključne riječi: alohtona flora, Cardamine L., Europa, invazivne biljke, korov, porodica Brassicaceae 


\section{INTRODUCTION}

The large Genus Cardamine L. (family Brassicaceae) is distributed worldwide, except in Antarctica. It is the biggest genus under the tribe Cardamineae (AL-SheHbaz et al., 2006), and due to the higher percentage of polyploidy and easy hybridization in the genus Cardamine (Lihová \& MARHOLD, 2006) identification at species level is always difficult. However, it is estimated that there are about 200 species today (Mandákoví et al., 2019). The greatest diversity of the genus is in the Far East and the Himalayas, with around 70 taxa (Al-ShenbAz, 1988). A great number of taxa are also present in North and Central America, the European Mediterranean and the Caucasus - circa 50 taxa in each area (Rollins, 1993; Lihové \& Marhold, 2006). Some taxa have cosmopolitan distributions and/or are invasive, e. g. Cardamine impatiens L. in USA (Loeb, 2009) or C. hirsuta L. in Japan (Matsuhashi et al., 2016). According to LiHová \& MARHOLD (2006) 54 well-defined species have been identified for Europe. Furthermore, eight Cardamine taxa were alien outside their native European range. Additionally, as alien plants in Europe, three more taxa with non-European origins were recorded: C. chelidonia L., C. corymbosa Hook. f. and C. parviflora L. (DraKe, 2009). However, this assertion is doubtful, because C. chelidonia is native in the north western part of South-Eastern Europe, eg. Croatia, Bosnia and Herzegovina, central and southern Italy (including Sicily) and Corsica (MARHold, 1996; Milović, 2015). Furthermore, the taxon C. parviflora is also of uncertain origin, with molecular evidence that favours an infraspecific level of the Euroasian and North American populations (Lihoví et al., 2006; Al-Shehbaz et al., 2010). Relatively recently a new taxon of this genus, C. occulta, was taxonomically resolved and recorded in many European countries (MARHold et al., 2016; Pliszko, 2020). Its native distribution is East Asia, but outside that area it has great invasive potential (MARHOLD et al., 2016). The only areas so far without data on the presence of this species are Scandinavia and Southeast Europe.

In Croatian flora, 24 taxa of the genus are listed (Nikolić, 2020), out of which 7 are endemic (KuČERA et al., 2010; NikOLić, 2020). Some Cardamine taxa are rarely noticed in Croatia, e. g. C. resedifolia L. and C. glauca Spreng., and some have been recorded in the last ten years, e. g. C. fialae Fritsch and C. parviflora L. (Kučera et al., 2010; PrLić, 2015; Nikolić, 2020). The species C. occulta had not been observed in Croatia until 2017 (HRUŠEVAR et al., 2018), when it was detected in a nursery near the Dalmatian city of Zadar (HrušEvar et al., 2018). After that, also in 2017, we realized that it was also present in at least one other Dalmatian area of Croatia, and decided to research the species in more detail. Therefore, the first aim of our study was to present a short history of the discovery and to explore two newly-detected sites of the new alien species in Croatia. Since C. occulta is unknown in Croatia, a further goal was to establish some features of the species to make its identification easier, specifically: taxonomical peculiarities and detailed plant description, with its distribution, growth and invasive preferences, and the creation of a determination key that will enable the differentiation of the new alien species C. occulta from similar species present in Croatia, i. e. C. flexuosa With. and C. hirsuta.

\section{MATERIAL AND METHODS}

The survey was conducted continuously between 2017 and 2021 at both sites at which the species C. occulta had been spotted. The sites were geocoded by a GPS device. Plant identifications were performed with specific determination keys and 
scientific articles (Verloove \& Gullón, 2012; Dirkse et al., 2015; Mansanet-Salvador et al., 2015; Cooke \& Heathcote, 2017; Šlenker et al., 2019; Verloove, 2020). The determination key was developed according to a comparison of the details of our field observations and the results of the work of other authors (MARHOLD et al., 2016; ŠLENKer et al., 2019). The nomenclature of the species C. occulta follows MARHOLD et al. (2016) and Powo (2021), and the nomenclature of other plants related to the presented research activities follows Nikolić (2020). Samples of several plant specimens of $C$. occulta were collected and deposited in the Herbarium Croaticum (ZA, voucher numbers 61756 - 61759) and in personal herbarium collections (Dario Hruševar, Dalibor Vladović).

\section{RESULTS AND DISCUSSION}

During the summer 2017, the first individuals of C. occulta were noticed in the plant nursery in Zemunik Donji, near the city of Zadar (Fig. 1), as a container weed of pine seedlings. The coordinates of the site are $44^{\circ} 06^{\prime} 35.2^{\prime \prime} \mathrm{N}$ and $15^{\circ} 23^{\prime} 18.2^{\prime \prime} \mathrm{E}$. Plants were similar to C. flexuosa and at first, it seemed that they belong to the C. flexuosa agg. However, some small differences in the morphology of the vegetative and generative structures were observed, which prompted us to perform a more detailed determination through the use of more specific determination keys and articles (VERloove \& Gullón, 2012; Dirkse et al., 2015; Mansanet-Salvador et al., 2015; Cooke \& Heathсоте, 2017). Precise determination enabled us to reveal a new weed species $C$. occulta, discovered for the first time in Croatia (HrušEvar et al., 2018). The appearance of this species has caused concern, due to its dense abundance and potential competition with pine seedlings for soil nutrition. This was exacerbated because somewhat later, in the same year, we noticed the species at a new Dalmatian site in a nursery in the city of Split (Fig. 1). The coordinates of this site are $43^{\circ} 30^{\prime} 51.2^{\prime \prime} \mathrm{N}$ and $16^{\circ} 29^{\prime} 58.8^{\prime \prime} \mathrm{E}$. There it grew in flowerpots with shoots of various perennials and palm trees. Since they appeared, the plants have been monitored continuously, and the populations in both nurseries are still present and getting denser every year. Nevertheless, individuals of them have not been discovered outside cultivation. However, due to their wellknown and documented invasiveness and the fact that the most common pathway of its introduction into an area is horticulture (Mandéková et al., 2019; Pliszko, 2020 etc.), it is probably only a matter of time before it is recorded outside cultivation. Namely, although the containers with seedlings in both nurseries are regularly washed and exposed to temperatures exceeding $40{ }^{\circ} \mathrm{C}, \mathrm{C}$. occulta is still present, both in covered and open parts of the nurseries. In our opinion summer drought is probably the main barrier that makes it difficult for the species to spread to the surrounding areas. However, caution with this species is necessary because the nursery in Zemunik Donji is located relatively near the Vrana Lake Nature Park, which can be an ideal habitat for the spread of this species outside cultivation. During all the years of observation, we noticed an interesting phenomenon in the nursery in Zemunik Donji. Namely, conifers (Pinus halepensis Mill., P. nigra J. Arnold, P. pinaster Aiton, P. pinea L., Cupresus sempervirens L.) and deciduous trees (Quercus pubescens Willd., Q. ilex L., Fraxinus ornus L., Robinia pseudoacacia L.) are equally grown in the nursery from seed material. However, in containers with conifer seedlings, the coverage of C. occulta is incomparably higher than in containers with deciduous trees, although the same substrate was used, and the frequency of watering does not differ. At first, it seems to us that 


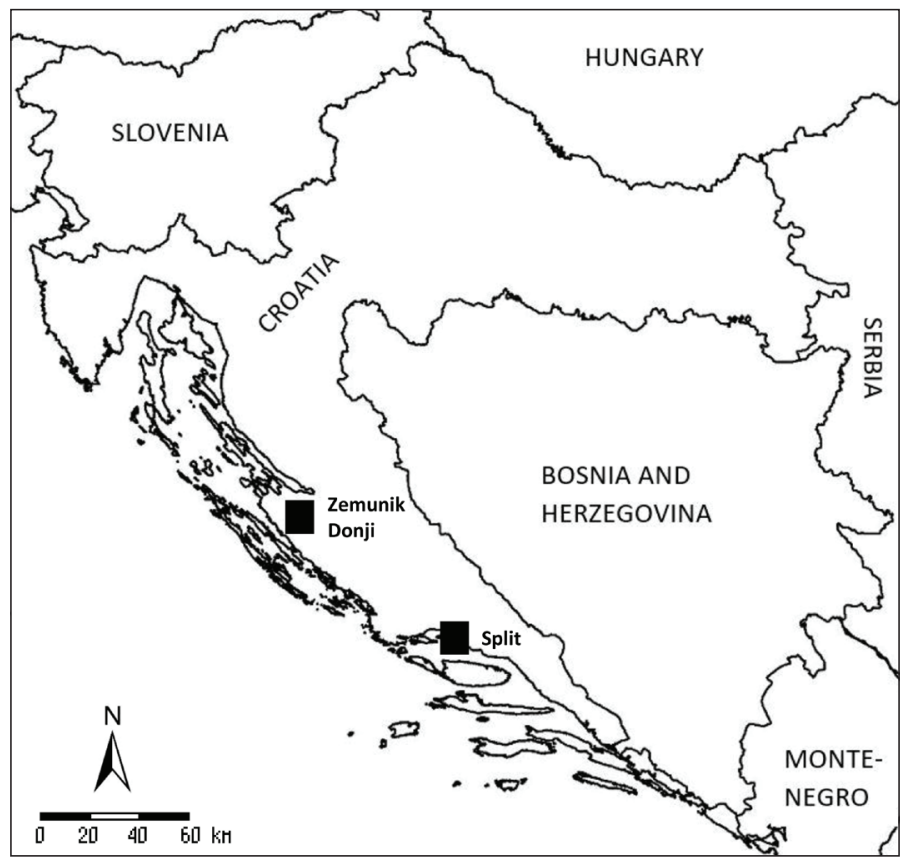

Fig. 1. Locations of the first sites of the species Cardamine occulta Hornem. in Croatia.

this may be because of an allelopathy effected by some deciduous species on $C$. occulta (maybe by oaks or black locust, eg. NASIR et al. 2005), and this speculation might be confirmed experimentally in the future. Even more so as we have not observed a similar phenomenon in the nursery in Split, and the fact is that oaks and black locust are not grown there. For now, since the plants of C. occulta occur in both places in containers and pots with different cultivated plants, we assume that these first occurrences of C. occulta in Croatia are rather the result of seeds imported to the nurseries in soil substrates than preferences related to specific cultivated plants. Also tending to support this assumption is the information that the species C. occulta has been observed and collected in flowerpots of unknown origin, but purchased in stores in the continental part of Croatia (AlEgro, 2021; Š EGOTA, 2021; personal communications).

Although the name C. occulta Hornem. is still not accepted by the World Checklist of Seed Plants (GovaerTs, 1999 - therein it is treated as a synonym of C. flexuosa), it is accepted by the IPNI (2021) and the Plants of the World Online (Powo, 2021). According to Powo (2021) synonyms of the species are: Barbarea arisanensis (Hayata) S.S.Ying, Cardamine arisanensis Hayata, C. autumnalis Koidz., C. brachycarpa Franch., C. debilis D.Don, C. decurrens (Blume) Zoll. \& Moritzi, C. flexuosa var. debilis (O.E.Schulz) T.Y.Cheo \& R.C.Fang, C. flexuosa subsp. debilis O.E.Schulz, C. flexuosa var. occulta (Hornem.) O.E.Schulz, C. hamiltonii G.Don, C. nasturtioides D.Don, Pteroneurum decurrens Blume. For example, it was frequently recorded under various names, such as $C$. flexuosa auct. non With, C. flexuosa subsp. debilis O.E. Schulz and Cardamine hamiltonii 
G. Don (Marhold et al., 2016). However, the latter two names are based on illegitimate name C. debilis D. Don, which must not be confused with C. debilis Banks ex DC. (MARHold et al., 2016).

Plants of C. occulta (Figs. 2, 3a-c) are mostly annual (rarely biennial), usually less than $30 \mathrm{~cm}$ tall (ŠLENKER et al., 2018). Stems are flexuous, branched, sometimes decumbent and rooting at the lowest nodes (RaAb-Straube \& Von Raus, 2014; Dirkse et al., 2015), glabrous or pubescent in basal part (Dirkse et al., 2015; ŠLenker et al., 2018).

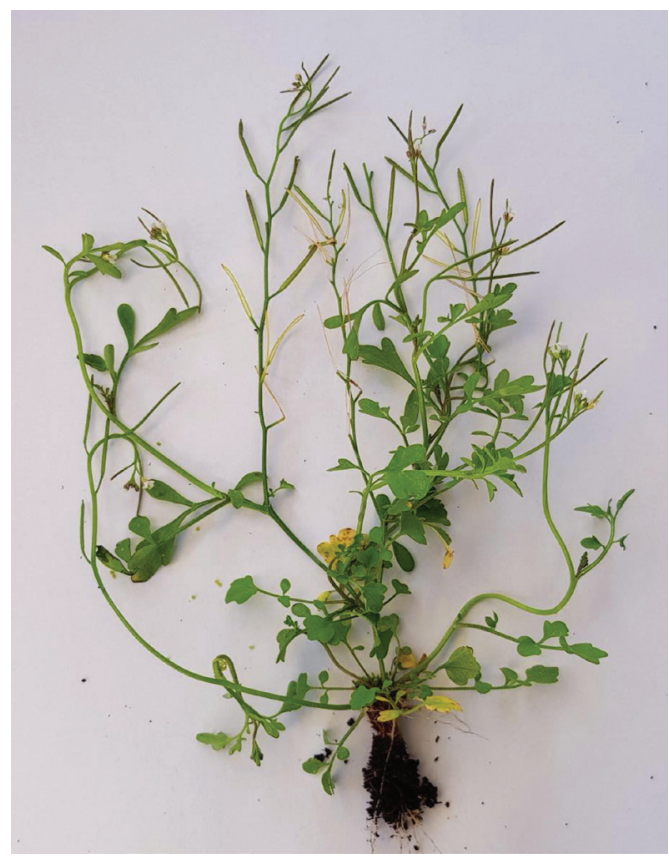

Fig. 2. Cardamine occulta Hornem.- plant habitus.
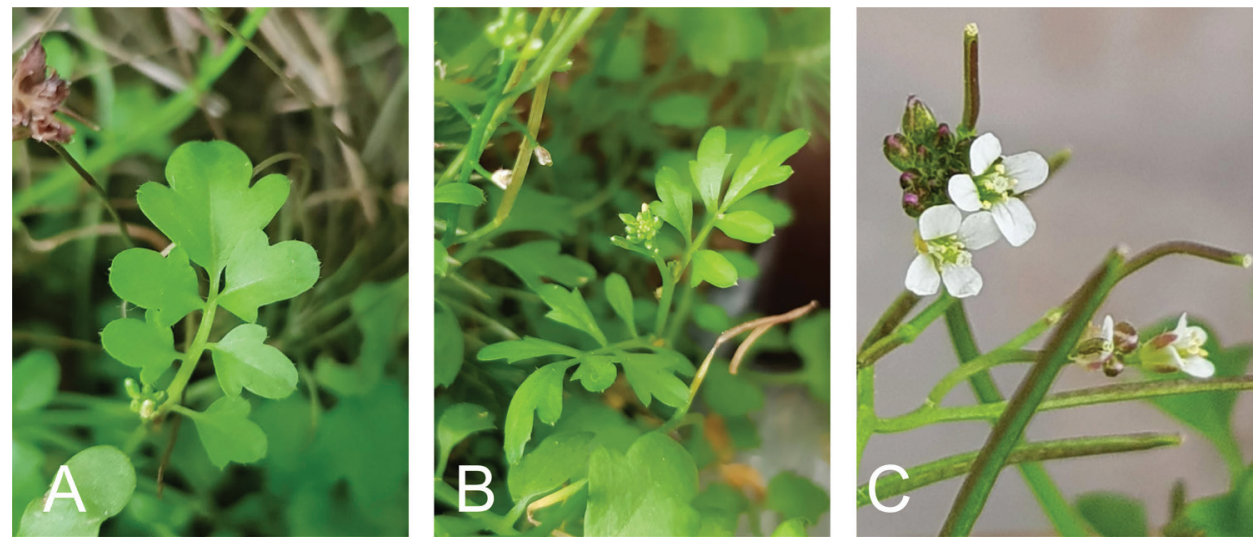

Fig. 3. Cardamine occulta Hornem.: a) lateral leaf; b) stem with leaves and flower buds; c) flowers and fruits. 
Leaves are without auricles (DIRKse et al., 2015), the upper side is mainly glabrous (Pliszko, 2020). Basal leaves do not form a rosette. The stem leaves have several to many sessile to petiolate leaflets (Mansanet-SaLVAdor et al., 2015). Terminal leaflet is reniform, broadly ovate or suborbicular, mostly 3 - 5 lobed, and lateral leaves are similar, but mainly 1-3 lobed. Inflorescence is racemus with an ascending rachis; petals are almost twice as long as sepals, six stamens are observed in flowers (ŠLENKER et al., 2018). Floral pedicels are divaricate to ascending, mostly short (1-1.5 mm), fruiting pedicels 3 - $5 \mathrm{~mm}$ long (RaAb-Straube \& Von Raus, 2014; Mansanet-Salvador et al., 2015), linear silique is up to 18 (24) mm in length (RAab-Straube \& Von Raus, 2014; ŠLENKER et al., 2018). Seeds are brown, oblong or sub-quadrate, without wings (Š́LENKER et al., 2018).

The species C. occulta is a natural hybrid, an octoploid taxon with the chromosome number $2 \mathrm{n}=8 \mathrm{x}=64$, and probably originated from the tetraploid parents C. scutata and C. kokaiensis (ŠLENKER et al., 2018; MANDÁKOVÁ et al., 2019).

It naturally grows in East Asia and prior to molecular evidence that it should be treated as a separate taxon (LiHoví et al., 2006; MARHOLD et al., 2016), the species was overlooked for Europe. However, although only much later recognized as a new taxon, C. occulta was first collected in Europe in Belgium in 1963 and in Italy in 1977 (Marhold et al., 2016; ŠLenker et al., 2018; Verloove, 2020). In other European areas, it was very often unnoticed due to morphological confusion with the similar species $C$. hirsuta and C. flexuosa (Crespo et al., 2013; Marhold et al., 2016; ŠLenker et al., 2019; Pliszko, 2020; Verloove, 2020). Knowledge about the distribution of C. occulta in Europe was greatly increased by research into the "alien Cardamine" at Lake Constance (BleEkER et al., 2008). Today, this native East Asian taxon is recorded for almost the whole of Europe with the exception of Scandinavia and South-eastern Europe. It was recorded in Austria, Belgium, Canary Islands, Crete, Cyprus, Czechoslovakia, France, Germany, Ireland, Italy, Netherlands, Poland, Portugal, Sardinia, Spain, Switzerland, United Kingdom (Marhold et al., 2016; Šlenker et al., 2018; Pliszko, 2020; Powo, 2021). It is also known as introduced species from areas of other continents, eg. Cuba, El Salvador, Mexico, Hawaii, New Zealand etc. (Mandákové et al., 2019; Powo 2021).

The species C. occulta blooms from the beginning of spring until autumn, with several generations per year (MANSANET-SALVADOR et al., 2015). Winter flowering has also been observed, enhanced by mild temperatures (BleEker et al., 2008; Dirkse et al., 2015). After germination, the plants will flower within two weeks (Dirkse et al., 2015). The taxon is prolific and produces a large number of seeds that spread rapidly through the neighbouring plant containers (MANSANET-SALVADOR et al., 2015), thanks to the explosive opening mechanism of the siliqua (cf. HofHuIs et al., 2016). The seeds are viable and able to germinate in the hot and humid conditions of the greenhouse, forming tapestries of small seedlings (MANSANET-SALVAdOR et al., 2015). It was also demonstrated that C. occulta seeds are much better adapted to flooding than C. hirsuta (YATsu et al., 2003), and floating seeds are the main vector of their dispersal on the Lake Constance (BleEker et al., 2008).

As a neophyte herbaceous plant C. occulta primarily occurs in anthropogenic habitats (CoOke \& HеAтнсоте, 2017) and humid environments, mostly associated with crops (especially in rice fields), orchards (MANSANET-SALVADOR et al., 2015), among cobblestones or paving stones, or on pavements, often in irrigated places (MARHOLD et al., 
2016). It is a common weed in plant nurseries and probably widely dispersed as a weed of container plants in many other parts of the world (VerLoove \& Gullón, 2012; Hepenstrick \& Hoffer-Massard, 2014), as is evidently the case with our recorded plants. However, this species is still very poorly known and probably overlooked in areas where it can be naturalised as an agricultural and horticultural weed (Verloove \& Gullón, 2012). For example, in Spain (Verloove \& Gullón, 2012), Italy (Verloove \& Ardenghi, 2015) and Central Europe (Bleeker et al., 2008) it colonised natural habitats, and in the area of the Lake Constance C. occulta showed invasive potential (Klausmeyer, 2006; Bleeker et al., 2008). As well as seeds and soil, possible vectors of introduction to new areas might be birds or tourists (BLEEKER et al., 2008; Mansanet-Salvador et al., 2015).

We paid particular attention to the comparison of this new taxon with the species C. flexuosa and C. hirsuta, which are present and well known in Croatia (Nikolić, 2020), and could be confused with C. occulta species. Namely, although the first two species differ in the number of chromosomes and genome sizes (cf. ŚLENkER et al., 2019), they are morphologically similar and therefore we suggest a key for their easier determination:

1. Plant with compact basal leaf rosette during anthesis and usually without or with only a few stem leaves, glabrous, terminal leaflet mostly entire, flowers with four stamens, fruit pedicels often erect. ................... hirsuta

Plant without basal leaf rosette during anthesis, flowers with six stamens, fruit

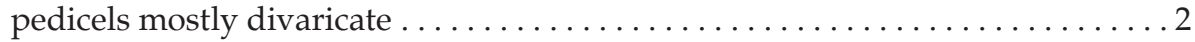

2. Dark green plant, stem with many leaves (usually $>4$ ), markedly hairy towards base; terminal leaflet partially toothed or lobed (up to seven) with shallow sinuses, floral pedicels $>3 \mathrm{~mm}$, siliqua $12-24 \mathrm{~mm} \ldots \ldots \ldots \ldots$. flexuosa

Pale green plant, stem with a few leaves (usually $<4$ ), most often hairless; terminal leaflet, at least in part, distinctly trilobed (up to five lobes), with deep and sharp sinuses, floral pedicels $<2,5 \mathrm{~mm}$, siliqua $10-18 \mathrm{~mm} . \ldots \ldots \ldots$. . occulta

To conclude, C. occulta has not been observed in the wild in Croatia or in most of the neighbouring countries (e. g. Slovenia, Serbia, Bosnia and Herzegovina and Montenegro) so far. Therefore, we hope that the proposed determination key and photos of plants will enhance possibilities of its recognition in cultivation, in the field and in herbarium material (e.g. in the case of re-determination of C. flexuosa and C. hirsuta, if necessary). The potential presence of the species $C$. occulta outside of cultivation must be taken into account, as it might become a future invasive species in the flora of Croatia, and, like most weeds, will be difficult or impossible to eradicate.

\section{ACKNOWLEDGEMENTS}

We would like to thank Antun Alegro and Vedran Šegota for sharing with us new information about C. occulta findings, as well as the two anonymous reviewers for valuable comments that improved the final version of the paper. 


\section{REFERENCES}

Al-Shenbaz, I. A., 1988: The genera of Arabidae (Cruciferae; Brassicaceae) in the southeastern United States. Journal of the Arnold Arboretum 69, 85-166.

Al-Shehbaz, I. A., Beilstein, M. A. \& KellogG, E. A., 2006: Systematics and phylogeny of the Brassicaceae (Cruciferae): an overview. Plant Systematics and Evolution 259, 89-120.

Al-Shehbaz, I. A., Marhold, K. \& Lihová, J., 2010: Cardamine Linnaeus. In: Flora of North America Editorial Committee (eds.), Flora of North America: North of Mexico, Volume 7, Magnoliophyta: Salicaceae to Brassicaceae. Oxford University Press, New York, Oxford, p. 464-484.

Bleeker, W., Klausmeyer, S., Peintinger, M. \& Dienst, M., 2008: DNA sequences identify invasive alien Cardamine at Lake Constance. Biological Conservation 141, 692-698.

Coокe, E. L. \& Heatнсоте, S. J., 2017: Cardamine occulta, another small white-flowered weedy Brassica, BSBI News 135, 73-74.

Crespo, M. B., Azorín, M. M. \& Camuñas, E., 2013: Novedades corológicas para la flora valenciana [New records for the flora of the Valencian Community (E of Spain)]. Flora Montiberica 55, 118-127.

Dirkse, G. M., Zonneveld, B. J. \& Duistermaat, L. H., 2015: Cardamine hamiltonii G. Don-Aziatische veldkers (Brassicaceae) in Nederland. Gorteria 37, 64-70.

Drake, J. A. (ed), 2009: Handbook of Alien Species in Europe. Invading nature: Springer series in invasion ecology 3. Springer, Knoxville, p. 160.

Govaerts, R., 1999: World Checklist of Seed Plants 3(1, 2a \& 2b). MIM, Deurne, p. 1-1532.

Hepenstrick, D. \& Hoffer-Massard, F., 2014: Un xénophyte asiatique du groupe Cardamine flexuosa: identification, nomenclature et génétique. Bulletin du Cercle vaudois de botanique 43, 69-76.

Hofhuis, H., Moulton, D., Lessinnes, T., Routier-Kierzkowska, A. L., Bomphrey, R. J., Mosca, G., Reinhardt, H., Sarchet, P., Gan, X., Tsiantis, M., Ventikos, Y., Walker, S., Goriely, A., Smith, R. \& HaY, A., 2016: A morphomechanical innovaton drives explosive seed dispersal. Cell 166(1), 222-233.

Hruševar, D., Mesaroš, J., Vladović, D., Vucić, A. \& Mitić, B., 2018: Cardamine occulta Hornem. - A new alien plant taxon in Croatia. In: Jelaska, S. D. (ed.), Book of Abstracts of the 3rd Croatian Symposium on Invasive Species with International Participation, Croatian Ecological Society, Zagreb, p. 97-97.

IPNI, 2021: International Plant Names Index. Published on the Internet http://www.ipni.org. The Royal Botanic Gardens, Kew, Harvard University Herbaria and Libraries and Australian National Botanic Gardens (retrieved: March 12th 2021).

Klausmeyer, S., 2006: Analyse von potenziellen Cardamine Hybriden in der Ufervegetation des Bodensees. State Examination Thesis, University of Osnabrück, Department of Systematic Botany, Osnabrück.

Kučera, J., Marhold, K. \& Lihová, J., 2010: Cardamine maritima group (Brassicaceae) in the amphi-Adriatic area: A hotspot of species diversity revealed by DNA sequences and morphological variation. Taxon 59(1), 148-164.

Linová, J. \& Marhold, K., 2006: Phylogenetic and diversity patterns in Cardamine (Brassicaceae) - a genus with conspicuous polyploid and reticulate evolution. In: Sharma, A. K. \& Sharma, A. (eds.), Plant genome: biodiversity and evolution, Volume 1C, Phanerogams (Angiosperms - Dicotyledons). Science Publishers, Enfeld, p. 149-186.

Linová, J., Marhold, K., Kudoh, H. \& Koch, M. A., 2006: Worldwide phylogeny and biogeography of Cardamine flexuosa (Brassicaceae) and its relatives. American Journal of Botany 93, 1206-1221.

Loeb, R. E., 2009: Biogeography of Invasive Plant Species in Urban Park Forests. In: Kohli, R. K., Jose, S., Singh, H. P. \& Batish, D. R. (eds.), Invasive Plants and Forest Ecosystems. CRC Press, Boca Raton, p. 110.

Mandáková T., Zozomová - Lihová J., Kudoh, H., Zhao, Y., Lysak, M. A. \& Marhold, K., 2019: The story of promiscuous crucifers: origin and genome evolution of an invasive species, Cardamine occulta (Brassicaceae), and its relatives. Annals of Botany 124(2), 209-220.

Mansanet-Salvador, C.J., Ferrer-Gallego, P.P., Ferrando, I. \& Laguna, E., 2015: Notas sobre el complejo taxonómico Cardamine flexuosa With. (Cruciferae) y su presencia en la Comunidad Valenciana. Flora Montiberica 59, 72-82.

Marhold, K., 1996: Typification of the Linnaean names of the genus Cardamine (Cruciferae). Botanical Journal of the Linnean Society 121, 111-131. 
Marhold K, Šlenker M, Kudoh, H. \& Zozomová - Lihová, J., 2016: Cardamine occulta, the correct species name for invasive Asian plants previously classified as C. flexuosa, and its occurrence in Europe. PhytoKeys 62, 57-72.

Matsuhashi, S., Kudoh, H., Maki, M., Cartolano, M., Tsiantis, M., Itagaki, T. \& Sakai, S., 2016: Invasion history of Cardamine hirsuta in Japan inferred from genetic analyses of herbarium specimens and current populations. Biological Invasions 18, 1939-1951.

Milović, M., 2015: Cardamine L. In: Nikolić, T., Milović, M., Bogdanović, S. \& Jasprica, N. (eds.), Endemi u hrvatskoj flori [Endemic taxa in Croatian flora, on Croatian]. Alfa, Zagreb, p. 135-147.

Nasir, H., Iqubql, Z., Hirdate, S. \& FujiI, Y., 2005: Allelopathic Potential of Robinia pseudo-acacia L. Journal of Chemical Ecology 31(9), 2179-2192.

Nikolić, T. (ed.), 2020: Flora Croatica Database. Department of Biology, Faculty of Science, University of Zagreb, http:/ / hirc.botanic.hr/fcd. (retrieved: November 16 ${ }^{\text {th }} 2020$ ).

Pliszko, A., 2020: First record of Asian Cardamine occulta Hornem. (Brassicaceae) in Poland. BioInvasions Records 9(3), 655-659.

Powo, 2021: Plants of the World Online. Facilitated by the Royal Botanic Gardens, Kew. Published on the Internet; http:/ / www.plantsoftheworldonline.org/ (retrieved: March 12 ${ }^{\text {th }} 2021$ ).

PrLić, D., 2015: Small-flowered bittercress, Cardamine parviflora L. (Brassicaceae), a new species of the Croatian flora. Acta Botanica Croatica 74(1), 151-157.

RaAb-Straube, E. \& Von Raus, Th., (eds.), 2014: Euro+Med-Checklist Notulae, 3 [Notulae ad floram euro-mediterraneam pertinentes 32]. Willdenowia 44, 287-299.

Rollins, R. C., 1993: The Cruciferae of Continental North America. Stanford University Press, Stanford.

Šlenker, M., Zozomová - Lihová, J, \& Marhold, K., 2019: Cardamine occulta - inconspicuous neophyte in Slovakia. Bulletin Slovenskej botanickej spoločnosti 41(1), 13-23.

Šlenker, M., Kudoh, H., Mandáková, T., Zozomová - Lihová, J. \& Marhold, K., 2018: Introduction of Cardamine occulta into Europe and origin of this species. Botanica Serbica 42(1), 41-41.

Šlenker, M., Zozomová - Lihová, J., Mandáková, T., Kudoh, H., Zhao, Y., Soejima, A., Yahara, T., Skokanová, K., Španiel, S. \& Marhold, K., 2018: Morphology and genome size of the widespread weed Cardamine occulta: how it differs from cleistogamic C. kokaiensis and other closely related taxa in Europe and Asia. Botanical Journal of the Linnean Society 20, 1-27.

Verloove, F., 2020: Cardamine occulta. Manual of the Alien Plants of Belgium. http:/ / alienplantsbelgium.be/content/cardamine-occulta (retrieved: October $12^{\text {th }} 2020$ ).

Verloove, F. \& Ardenghi, N. M. G., 2015: New distributional records of non-native vascular plants in northern Italy. Natural History Sciences. Atti della Societa Italiana di Scienze Naturali e del Museo Civico di Storia Naturale di Milano 2, 5-14.

Verloove, F. \& Gullón, E. S., 2012: New records of interesting vascular plants (mainly xenophytes) in the Iberian Peninsula. II. Flora Mediterranea 22, 5-24.

Yatsu, Y., Kachi, N. \& Kudoh, H., 2003: Ecological distribution and phenology of an invasive species, Cardamine hirsuta L., and its native counterpart, Cardamine flexuosa With., in central Japan. Plant Species Biology 18, 35-42. 